\title{
Prevalence of Schistosoma haematobium among Primary School Children in Girei Local Government Area, Adamawa State, Nigeria.
}

\author{
${ }^{* 1}$ R.S. Naphtali, ${ }^{2}$ M.B. Yaro ${ }^{1}$ M. Arubi \\ 1. Department of Zoology, Modibbo Adama University of Technology, Yola. Nigeria \\ 2. Department of Biology, School of Sciences Adamawa State, College of Education Hong \\ Nigeria
}

\begin{abstract}
A study on Schistosoma haematobium among primary school children in Gerei Local government Area of Northeastern Nigeria was conducted to determine the infection prevalence and relationship among primary school children and to assess infection rate in respect to age and parents occupation of the subjects. A total of three hundred school children were randomly selected from two primary schools within the Local Government Area. The samples was examined for the ova of Schistosoma haematobium using sedimentation technique.The overall prevalence rate of $33.3 \%$ was observed. Higher infection rate was observed among males, 64(21.3\%) than their female, 40(13.3) counterpart. However, there was no statistical significant difference $(P>0.05)$. Prevalence was also noted to be higher among Pupils 10 years and above, $19.0 \%$ followed by age group 8-9 years, 10.7\%, while the least was recorded among pupils within 6-7 years 5.0\%. Chi-square revealed that, there was association between age group and rate of infection $(p<0.05)$. Infection rate in relation to parents' occupation implies that, children whose their parents are farmer had the highest infection rate of $20.7 \%$ followed by those whose their parents are civil servants with $9.0 \%$ infection rate. Traders' children had the least with $5.0 \%$.
\end{abstract}

\section{Introduction}

Human schistosomiasis, also known as bilharziasis occurs due to Schistosoma haematobium. Schistosomiasis is a parasitic disease cause by several species of trematodes (platyhelmenthes or flukes infection), a parasitic worm of genus Schistosoma (Central Intelligence Agency [CIA], 2007). It is widely spread ranking second to malaria in terms of socio-economic and public health significance in tropical and sub-tropical areas. It is most prevalent among water-borne diseases, with a very great risk on rural population (Biu et al., 2000). They also reported on the incidence of the disease in Northeastern Nigeria where they limit their study to Maiduguri metropolis.

About 200 million people worldwide are estimated to be infected with S. haematobium of which $70 \%$ live in sub-saharan Africa. Uneke and Egede, (2009). Infection with schistosoma species does not always result in clinical manifestation of disease and many infections are asymptomatic (Uneke and Egede, 2009). Schistosoma. haematobium infection however could cause anemia, haematoria, dysuria, nutritional deficiency, lesion of bladder, kidney failure and elevation risk of bladder cancer and also can cause growth retardation in children.

Transmission of urinary schistosomiasis is depended on availability of specific snail host and human activities with water contacts (WHO, 2010). Therefore, the risk and emergence of urinary schistosomiasis is attributed to the range of snail habitat promoted by water development schemes such as dam construction (Jamison et al., 2006). School age children were thought to have frequent water contact which exposed them to schistosomiasis, therefore they have association with schistosomiasis problem (Deribe et al., 2011 and Bala et al., 2012).

\section{Materials and Methods}

The study was conducted in Girei Local government Area Adamawa of State, Nigeria. The Area is located between latitude $9^{\circ} 11$ and $9^{\circ} 38$ north and longitude $12^{\circ} 21$ and $12^{\circ} 49$ East. The choice of the study area was based on reports from primary health care, clinics and hospitals.

Children between age group of six years and above were selected randomly from all the respective classes. The students were sensitized on urinary schistosomiasis and the transmission route and how to collect the sample without contamination. Three hundred (300) urine samples was collected using simple random sampling method. A dry clean leak proof, well labeled, wide mouthed plastic specimen bottles were given to the participants for sample collection. They were further informed to collect the last few drops of their morning urine because the last drops often contain high number of eggs (Cheesbrough, 2002). Urine collected was immediately taken to laboratory to examine the presence of schistosome ova using sedimentation method. Each 
sample was centrifuge at 1500rpm for 5 minutes and the prepared slides were examined microscopically using $\mathrm{x} 10$ and $\mathrm{x} 40$ objective lens. Chi-square was used to test the differences and association. $\mathrm{p}=0.05$ was used to determine the significance at $\mathrm{p}<0.05$.

\section{Results}

The overall prevalence of those that are infected with S. haematobium in the study area was 104(34.7\%) (Table 1). The distribution of infection according to sex revealed that male, 64(21.3\%) pupils were more infected than females, 40(13.3\%) (Table 2). Prevalence of S. haematobium infection was common across all the age groups and peaked among age group 10 years and above with $37.7 \%$ in Girei I and $42.1 \%$ in Girei II and low infection was recorded among age group 1-7 years with $25.0 \%$ in Girei I and II (Table 3), with statistical significant difference $(\mathrm{p}<0.05)$. The prevalence of $S$. haematobium with reference to parents occupation signified infection rate among pupils whose their parents are farmer with $20.7 \%$ and relatively followed by those whose parents were civil servant with $9.0 \%$, while children of traders had the lowest infection rate of $5.0 \%$ as shown in table 4 , and the was statistical significant difference $(\mathrm{p}<0.05)$.

Table 1: Distribution of Schistosoma haematobium Infection in Relation to School

\begin{tabular}{lccc}
\hline School & No. Examined & No. infected & \% infected \\
\hline Girei I & 100 & 34 & 34.0 \\
Girei II & 200 & 70 & 35.0 \\
Total & 300 & 104 & 34.7 \\
\hline
\end{tabular}

$\mathrm{X}_{\text {cal }}^{2}=5.369$, df at $0.05=3.841$

Table 2: Prevalrnce of Schistosoma haematobium Infection by Gender

\begin{tabular}{|c|c|c|c|c|c|c|c|c|}
\hline \multirow[t]{2}{*}{ School } & \multicolumn{3}{|c|}{ Male } & \multicolumn{3}{|c|}{ Female } & \multirow{2}{*}{$\begin{array}{l}\text { Total } \\
\text { No. } \\
\text { infected }\end{array}$} & \multirow{2}{*}{$\begin{array}{l}\text { Total } \\
\% \text { infected }\end{array}$} \\
\hline & $\begin{array}{l}\text { No. } \\
\text { Examined }\end{array}$ & $\begin{array}{l}\text { No } \\
\text { infected }\end{array}$ & $\begin{array}{l}\% \\
\text { infected }\end{array}$ & $\begin{array}{l}\text { No. } \\
\text { Examined }\end{array}$ & $\begin{array}{l}\text { No } \\
\text { infected }\end{array}$ & $\begin{array}{l}\% \\
\text { infected }\end{array}$ & & \\
\hline Girei I & 68 & 24 & 35.3 & 32 & 10 & 31.3 & 34 & 34.0 \\
\hline Girei II & 115 & 40 & 37.0 & 85 & 30 & 32.6 & 70 & 35.0 \\
\hline Total & 185 & 64 & 21.3 & 117 & 40 & 13.3 & 104 & 34.7 \\
\hline
\end{tabular}

Table 3: Distribution of Schistosoma haematobium Infection in Relation to Age group

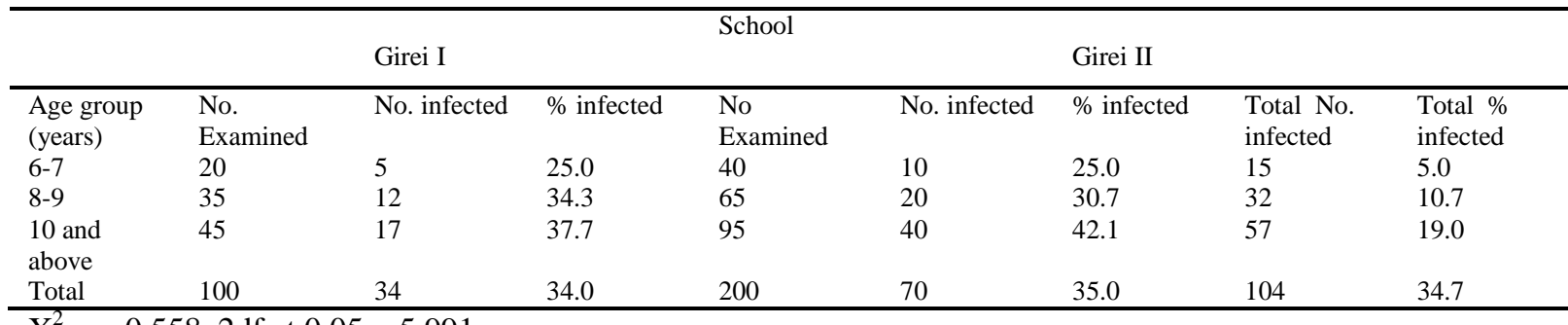

$\mathrm{X}_{\text {cal }}^{2}=0.558,2 \mathrm{df}$ at $0.05=5.991$

Table 4: Distribution of Schistosoma haematobium infection in Relation to parent's occupation

\begin{tabular}{|c|c|c|c|c|c|c|c|c|c|c|}
\hline School & $\begin{array}{l}\text { No. } \\
\text { Examined }\end{array}$ & $\begin{array}{l}\text { Farmer } \\
\text { No. } \\
\text { infected }\end{array}$ & $\begin{array}{l}\% \\
\text { infected }\end{array}$ & $\begin{array}{l}\text { No. } \\
\text { Examined }\end{array}$ & $\begin{array}{l}\text { Trader } \\
\text { No. } \\
\text { infected }\end{array}$ & $\begin{array}{l}\% \\
\text { infected }\end{array}$ & $\begin{array}{l}\text { No. } \\
\text { Examined }\end{array}$ & $\begin{array}{l}\text { Civil } \\
\text { servant } \\
\text { No } \\
\text { infected }\end{array}$ & $\begin{array}{l}\% \\
\text { infected }\end{array}$ & $\begin{array}{l}\text { Total No./ } \\
\% \text { infected }\end{array}$ \\
\hline Girei I & 45 & 19 & 42.2 & 20 & 5 & 25.0 & 35 & 10 & 28.6 & $34(34.0)$ \\
\hline Girei II & 110 & 43 & 39.1 & 35 & 10 & 28.6 & 55 & 17 & 30.9 & $70(35.0)$ \\
\hline Total & 115 & 62 & 20.7 & 55 & 15 & 5.0 & 90 & 27 & 9.0 & $104(34.7)$ \\
\hline
\end{tabular}

$\mathrm{X}^{2}$ cal $=0.361,2 \mathrm{df}$ at $0.05=5.991$ 


\section{Discussion}

The result of this study demonstrated a prevalence rate of 104 (34.7\%) of urinary schistosomiasis among primary school pupils of Girei Local Government Area Adamawa State, Nigeria. There was no doubt in the result as it agrees with the finding of Soares, et al. (2004) who stated that use of snail contaminated water for domestic purpose and leisure activities could be considered as risk factor for schistosome infection. The finding is also relatively in line with the research conducted by Biu, et al. (2009) who noted the prevalence of $S$. haematobium as $24.3 \%$ and Mafiana, et al. (2003) and disagrees with the work of Olalubi et al. (2013). This differences could be as a result of environmental hygiene condition that might exist among the study areas.

This study also revealed that males had higher prevalence rate of infection than the females. This agreed with the findings by Nworie et al. (2012); Okoli, et al. (1994) and Shashie, et al. (2015), but contrary to the finding of Olalubi, et al. (2013) who recorded high infection in females $(61.0 \%)$ than males $(39.0 \%)$. This could probably be due to females being more exposed to natural body of water than the males. School children between 10 years and above had the highest infection rate with 37.7\%.This finding agrees with that of Shashie, et al. (2015) and Biu, et al. (2009) who recorded high cases of S. haematobium infection among pupils aged 1015 years. It is well noted in this study that pupils whose parents were farmers had the highest infection rate and relatively followed by those whose parentswere civil servants and traders. This is in accord with the findings of some authors such as Shashie, et al. (2015); Ayele et al. (2008); Abou-zeid, et al. (2013) and Lengeler, et al. (2002).

\section{Conclussion and Recommendation}

This study has clearly demonstrated the occurrence of S. haematobium infection in the study area. The infection recorded could probably be due to few reasons, such as unhealthy environment, socio-cultural issues, lack of public menities, such as toilet, potable water supply, poverty, ignorance, inadequate access to healthcare and lack of proper sanitation and increased environmental contamination. Government should put emphasis on the above mentioned factors in educatin the community as well as providing the necessary amenities, de-worming of primary school aged children.

[1]. Ayele, B., Erko, B., Legesse, M., Hailu, A. and Medhin, G. (2008). Evolution of circulating Cathodic Antoen (CCA) strip for diagnosis of urinary schistosomiasis in Hossaba School children, Afar, Ethiopia. Parasite. 15: 69-75.

[2]. Abou-zeid, A.H., Abkar, T.A. and Mohammed, R.O. (2013). Schistosomiasis infection among Primary School students in a war Zone, Southern Kordofan State, Sudan: A Cross Sectional Study. BMC Public Health. 13:643.

[3]. Biu, A.A., Kolo, H.B. and Agbadu. (2009). Prevalence of Schistosoma haematobium Infection in School aged Children of Konduga Local Government, Northeastern Nigeria. International Journal of Biomedical and Health 5: 181-184.

[4]. Biu, A.A., Nwosu, C.O. and Akuta, A. (2000). The Incidence of human Schistosomiasis in Maiduguri, Northeastern Nigeria. Bioscience Res. Comm. 12(1): 9-11.

[5]. Bala, A.Y., Ladan, M.U. and Mainasara, M. (2012). Prevalence and intensity of Urinary Schistosomiasis in Abarma Village, Gusau, Nieria. A preliminary Investigation. Sci. World J. 7(2): 1-4.

[6]. Central Intellience Aency (CIA). Schistosomiasis. The Schistosomiasis. World Fact-book. 2007, 4.

[7]. Cheesbrough. M (2002). Clinical features and pathology of chistosoma. Medical Laboratory manual for tropical Countries (second edition). 1:331. Cambridge University Press.

[8]. Deribe, K., Eldaw. A., Hadziabduli, S., Kailie, E., Omar, M.D. and Mohammed, A.E. (2011). High Prevalence of Urinary Schistosomiasis in Two Communities in South Darfur: Implication for Interventions. Parasite Vectors. 4:14.

[9]. Jamison, T.D., Breman, G.J., Measham, R.A., Alleyne, G., Claeson, M. and Evans B.D. (2006). Disease Control Priorities Project. Disease Control Priorities in Developing Countries. ${ }^{\text {nd }}$ ed. Washington DC . The World Bank.467-482.

[10]. Lengeler, C., Utzinger, J., Tenner, M. (2002). Questionnaire for Rapid Screening of Schistosomiasisin sub-Saharan Africa. Bull World Health Organ. 80:235-42.

[11]. Mafina, C.F., Ekpo, U.F. and Ojo, D.A. (2003). Urinary Chistosomiasis in Preschool Children in Settlements around Oyan Reservoir in Ogun State, Nigeria. Implication for Control. Tropical Medicine International Health. 8(1): 78-82.

[12]. Nworie, O., Nya, O., Anyim, C., Okoli, C.S., and Okonkwo, E.C. (2012). Prevalence of Urinary Schistosomiasis amon Primary School children in Afikpo North Local Government Area of Ebonyi State. Scholars Research Library 3(8).

[13]. Okoli, E.I. and Odaibo, A.B. (1994) Tropical Medicine International Health. 4(s), 308-315.

[14]. Olalubi, A. Olowasogo and Olukunle, B. Fagbemi. (2013). Prevalence and Risk Factors of Schistosoma haematobium infections amon Primary School Children in Igbokuta Village, Ikorodu North Local Government Lagos State. Journal of nursing and health Science (IOSR-JNHS). 2(6): 62-68.

[15]. Shashie, Geleta., Agersew, Alemu., Sisay, Getie., Zeleke, Mekonnen. and Berhuna, Erko. (2015). Prevalence of Urinary Schistosomiasis and Associated risk Factors Among Abobo Primary School children in Gambella Regional State, Southwestern Ethiopia: A Cross Sectional Study. Journal of Parasite and Vector 8:215. 822

[16]. Soares, M., Berreto, M.G., Silva, D.A., Pereira, J.B., Moza, O. G., Calcado, M.S. and Maspew, R. (2004). Schistosomiasis is in low prevalence area. Incomplete urbanization increasing risk of infection in Paracambi, Brazil, Mem. Institution OsWaldoCruz 90 (4): 451-8.

[17]. Shashie, G., agersew, A., Sisay, G., Zeleke, M. and Berhanu, E. (2015). Prevalence of urinary schistosomiasis and associated risk factors among Abobo Primary School children in Gambella regional State, Southwestern Ethiopia: a cross sectional study. Journal of parasites and vectors. 215 (8): 822-825.

[18]. Uneke, C.J., Egede, M.U. (2009). Impact of Urinary Schistosomiasis on Nutritional Status of School Children in Southeastern Nigeria. The Internet Journal of Health. 9(1).

[19]. World Health Oranizatin. (2010). Working to Overcome the Global Impact of Neglected Tropical Disease First WHO report on Nelected Tropical Diseases. Geneva. 132 